\title{
An insight into entrepreneurship education practices in Technical and Vocational Education and Training institutions
}

\author{
Abede Jawara Mack ${ }^{1,2^{*}}$, Daniel White ${ }^{1,2}$ and Osiris Senghor ${ }^{1,3}$
}

\author{
* Correspondence: \\ doctoralstudent21@gmail.com \\ ${ }^{1}$ University of Trinidad and Tobago, \\ Lot 74-98 O'Meara Industrial Estate, \\ Arima, Trinidad and Tobago \\ ${ }^{2}$ Talparo, Trinidad and Tobago \\ Full list of author information is \\ available at the end of the article
}

\begin{abstract}
Technical and Vocational Education and Training (TVET) and entrepreneurship education have always been used as a vehicle towards economic and social transformation within many nations. With this in mind, the research investigates the entrepreneurship education practices in TVET institutions in Trinidad and Tobago. A quantitative study utilising a face-to-face survey was conducted with 446 TVET students from four TVET institutions from all geographical locations in Trinidad and Tobago. Correlation analysis and logistic regression were performed to assess the views and significant relationships involving students' interest and entrepreneurship education practices. The results of this study have important implications for TVET institutions. Students' interest in pursuing entrepreneurship was very high, and it tells a very good narrative that persons want to be an entrepreneur. Survey data revealed that $98 \%$ of respondents were interested in pursuing entrepreneurship as a career path. However, with the absence of an adequate platform or systems at the TVET institutions, students are not engaged in entrepreneurial paths in any significant way.

Keywords: Entrepreneur, Entrepreneurship, Entrepreneurship education, Skills training, TVET, TVET institution, Trinidad and Tobago
\end{abstract}

\section{Introduction}

According to Nwachukwu (2014) many nations both in the developing and developed world has seen TVET as a priority by ministers resonsible for edcuation. The reason being for these priorities is because TVET is keen in reducing poverty and enhancing national development (Nwachukwu 2014). Phillip O. Nwachukwu. (2014). TVET provides an impetus geared towards the development of young people, and it is an avenue where they can earn an income and confront unemployment. The rationale for placing high importance on TVET in our developing world is that our population of young people between the ages of 15-30-year-olds is rising, and according to a World Bank report, unemployment is leading among this age group which equals to nearly half of the world's unemployed (Aring, 2011). Additionally, a deficiency of skills that are valued in global and local economies limits economic growth, jobs, and income. TVET is seen as a mechanism for developing young people both in and out of school and can be used as an instrument to assist in this global dilemma of unemployment (Aring, 2011).

(C) The Author(s). 2019 Open Access This article is distributed under the terms of the Creative Commons Attribution 4.0 International License (http://creativecommons.org/licenses/by/4.0/), which permits unrestricted use, distribution, and reproduction in any medium, provided you give appropriate credit to the original author(s) and the source, provide a link to the Creative Commons license, and indicate if changes were made. 
Anderson (2009) contends that TVET is first developed in the circumstance surrounding the industrial revolution in Europe and North America as part of a philosophy of 'productivism'.

Although many studies have shown the importance of entrepreneurship education practices in TVET, this is limited or non-existent in T\&T. There is no data to suggest TVET has made strides or embark upon entrepreneurial education in T\&T. The authors took the opportunity to explore the entrepreneurship education practices of TVET institutions within T\&T to ascertain the level of entrepreneurial activity taking place within their institutions.

It has been debated that the pursuit of adeptness and economic returns was the fundamental dynamic of the new industrial approach. This perspective of TVET was perceived to have a profoundly influential purpose in providing the vital human capital required by commerce (Anderson, 2009). There is an interdependence between TVET and sustainable economic development (Beardwell, Holden, \& Claydon, 2004).

The four TVET institutions that comprised the study provide vocational training throughout many locations in T\&T. Institution 1 is a training institution, offering programmes such as the Journeyman Programme, Master Craftsman Certifications in Mechanical, Electrical/Electronic and Mechatronics, Engineer-In-Training, Welding, and other expert and personalised training programmes. The institution offers Life Skills Training to all students, in which entrepreneurship is a unit (minute aspect) of a wider module Employment and Financial Management Skills.

Institution 2 was set up to be a self-sufficient training institution connecting state, industry, and global institutions. At present, this institution has trained over 12,000 craftsmen and over 120,000 persons in information and communications technology. Institution 2 offers TVET courses in heavy equipment operator, electrical installation, automotive services, welding, instrumentation, plumbing, masonry, and machine shop, among many other courses. The institution offers Life Skills Training to all students, in which entrepreneurship is a unit (minute aspect) of a wider module Employment and Financial Management Skills.

Institution 3 aims are to utilise teaching that is of high caliber, use infrastructure and facilities that are of a high standard, and render quality services that meet professional benchmarks. The school offers short courses to bachelor degrees. Institution 3 runs courses in culinary management, food and beverage, baking and pastry arts, hospitality operations, and hospitality management, among many others. Currently, the institution offers entrepreneurship education as an option within their various hospitality programmes.

Institution 4 has progressed into an institute that meets the labour market demands of the industry. The entity focuses on the unemployed youth, retrenched employees, and displaced citizens between 15 and 60 years. Institution 4 has training locations throughout the length and breadth of T\&T, with the focus of full-time training centres, part-time centres, and community-based projects. Some of the programmes include cosmetology, tour guiding, plumbing, welding, carpentry, and electrical, among many others. The institution presently offers entrepreneurship education as an option; students most times pursue a craft programme first and then enrolled in the microentrepreneurship class, which is optional, and students are exposed to 144 contact hours before graduating. 


\section{Literature review}

Making a case for economic development in Tanzania, it was purported that a streamlined TVET system that is geared towards entrepreneurship development will benefit unemployed graduates. Focusing on the transportation network, it was argued that the implementation of the required infrastructural development in rail and road networks, utilities, and port facilities can enhance trade and productivity and stimulate economic development for the society (Myamba, 2013). Many policymakers and academics have argued about the value and benefit entrepreneurship brings to a nation's development (Kelley, Bosma and Amorós 2011). Entrepreneurship provides a catalyst for national competitiveness and economic development (Kelley, Bosma and Amorós 2011). In a study carried out in Trinidad and Tobago (T\&T) by the University of the West Indies (UWI), it was found that $2.5 \%$ of graduates sampled were involved in entrepreneurial activity or self-employed (Ministry of Tertiary Education and Skills Training, 2015). According to Ramkissoon-Babwah (2012), the government of T\&T has made attempts to grow the small business sector in T\&T by a methodical and calculated approach; all of this is done with the anticipation to encourage entrepreneurship as a vehicle of growth and employment generator. Based on the Global Entrepreneurship Monitor (GEM 2010) report, (done by (Kelley, Bosma and Amorós 2011) the Government of Trinidad and Tobago has harmonised the activities of development agencies with a focus on micro, small, and medium enterprises (MSMEs), improved access to seed capital and markets, and provided human resource development and training in entrepreneurship, especially in sectors of society hardest hit by the recession, global economic crisis, and structural adjustments (Ramkissoon-Babwah, 2012). According to Ramkissoon-Babwah (2012), the small business sector is regarded as a driver to transform and diversify T\&T's economy in a radical way. If T\&T is to achieve sustainable development and grow its local supply of entrepreneurs, the nation needs to create an entrepreneurship education model to support these outcomes (Ramkissoon-Babwah, 2012). There needs to be a swing favouring skills/competencies-based education and training, which would facilitate the advancement of entrepreneurship and business creation within T\&T (Ramkissoon-Babwah, 2012).

It has been argued that society needs men and women that are efficient in creating entities that would aid in mitigating the harmful effects of mass unemployment and poverty which entrepreneurial skills in TVET offers (Maigida, Saba, \& Namkere, 2013). Entrepreneurship education offers learners an opportunity to become business owners (Edmond, Oluniyi, Isaiah, \& Garba, 2014). Contemplating the arguments favouring TVET and entrepreneurship education, the research intends to uncover the practices of entrepreneurship education within four TVET institutions within T\&T.

Research has shown in developing countries that micro, smal,l and medium enterprises are very important towards economic and social advancements especially since it can employ many persons (Tambunan, 2019).

The utilisation of micro and small enterprises is seen the world over as a vital basis for employment or business prospects for young people; these undertakings are imperative development towards GDP (Tambunan, 2019). The role of these enterprises as mention by Tambunan (2019) highlights in a very significant way the value and importance of entrepreneurship. These entities are very paramount tools for economic and social progress. Not to mention, having such enterprises in the form of TVET 
enterprises will provide significant value to the development and progress of TVET in T\&T and provide a platform and a vehicle that can produce employment. The study seeks to highlight the practices of the institutions to ascertain what level of entrepreneurship activity is taking place at the institutions.

\section{Methodology}

\section{Purpose of the study}

The purpose of this study was to explore the practices involving entrepreneurship education within four TVET institutions. Four research questions served to focus on this investigation:

1. Are there any linkages between students' interest in pursuing entrepreneurship and students being exposed to entrepreneurship education?

2. Are TVET students being furnished with adequate vocational skills training that would prepare them to become entrepreneurs?

3. Is there any connection between students' interest in entrepreneurship and state support and incentives?

4. Is there a relationship between interest and attitude involving TVET students towards entrepreneurship?

\section{Participants}

The total population comprised of 7176 participants, and the researcher gathered data from 446 respondents. The study used a 5\% margin of error and a $95 \%$ confidence level. According to Singh and Masuku (2014), a 95\% confidence level with a 5\% of margin of error means that 95 out 100 samples will be a reflection of the true value of the population. Cluster sampling occurs when it is difficult or unlikely to obtain an exhaustive list of participants from a population (Boxill, Chambers, \& Wint, 1997). A cluster sample of 446 students was selected to participate in the study from the fifteen (15) geographical locations of T\&T from the four TVET institutions. The respondents pursued various TVET programmes all ranging from 18-50 years of age. Using an established table is another way to determine sample size (Singh \& Masuku, 2014) as cited by Glenn (1992). The sample size used was 446 TVET students, distributed across four institutions with a total population size of 7176 students. According to Singh and Masuku (2014), for a population size of 9000, a sample size of 383 is acceptable for a precision level $\pm 5 \%$ and a $95 \%$ confidence level and $P=0.5$.

\section{Instrument}

The data was analysed using Statistical Package for the Social Sciences (SPSS) software. The variables were put into their correct form utilising the SPSS software, and checks were made for missing values. The study incorporated varioussurvey questions which included the following:

1. Likert-type scale questions

2. Rating scale questions

3. Multiple choice questions 
4. Semantic differential scale questions

The questions focused on the following four areas:

1. Demographics

2. Students interest in entrepreneurship

3. The TVET institutions ability to prepare graduates to become entrepreneurs

4. Evaluating the systems in place to support entrepreneurship endeavours

Four hundred and forty-six (446) TVET students from four institutions were asked to indicate their level of agreement with the above questions by placing a tick in the appropriate box on a 5-point Likert-type scale, ratio question or closed-ended questions, with 1 representing strong disagreement and 5 representing strong agreement.

The survey was administered by hand, and the respondents were required to express their opinions involving entrepreneurship education at their institution. The instrument was pilot-tested, and feedback from that activity was used to improve the instrument before formally distributing the questionnaires to the research sample. Cronbach's alpha was used to measure internal consistency or reliability for the level of exposure (14 items) and student attitude (12 items) of the items used in the Likert scale and the rating scale. The result was .739 , which indicates a satisfactory level of internal consistency for the items used in the scale.

The study utilised inferential statistics, to generate data. According to Boxill et al. (1997), correlation speaks of strength involving two variables that have a relationship between them. The author would have incorporated this statistical test within this study as it provided many relevant answers to the discussion on TVET and entrepreneurship education within T\&T. The correlation that was tested showed a positive and significant relationship between exposing students to entrepreneurship (independent variable) and students' interest in entrepreneurship (dependent variable). According to Gallo (2015), regression analysis is a mathematical method to determine which variables have an impact on each other. The authors used the regression analysis to determine the strength of the independent variable (exposing students to entrepreneurship education) to determine what effect it has on the dependent variable (students' interest in entrepreneurship), which showed there was an effect not a major effect but significant. Also, the other independent variables which included student preparedness, support, and incentives were also measured against the dependent variable: students' interest in entrepreneurship.

\section{Results}

The response rate was $74.33 \%$.

Institutions 3 and 4 would have limited students; institution 3 classes had ended, questionnaires were administered during the students' registration period, and there were a limited amount of students that came during the registration period. Also, institution 4 programme activities came to an end during that period (2018), so there was only one class available in one location to gather data. Most of the participants lived in the Couva/ Tabaquite/Talparo Regional Corporation which is represented by $21 \%(n=93)$ and $16 \%$ $(n=61)$ of participants resided in Tobago, while $14 \%(n=61)$ reside in the Chaguanas Borough Corporation. Penal/Debe Regional Corporation represented 9\% $(n=39)$ of 
persons. The 11 remaining municipalities would account for $40 \%$ of residential addresses of the participants.

There was a 92\% $(n=402)$ of sample representing 18-25-year-olds pursuing TVET programmes, only $5 \%(n=22)$ were $26-35$ years of age, $2 \%(n=9)$ were $36-45$ years of age, and $0 \%(n=1)$ was 46 years and over (Table 1$)$. This showed that a high percentage of young people pursued TVET programmes. Most persons pursued diploma programmes from the various institutions which stood at $76 \%(n=334)$, students that pursued certificates stood at 20\% ( $n=88)$, associate degrees represented $3 \%(n=4)$, and bachelor's degrees was less than $1 \%(n=4)$. Males represented $85 \%(n=377)$ whereas female stood at $15 \%(n=66)$. Six major TVET courses were featured which showed the following: $n=103$ pursued auto mechanics, $n=85$ took part in electrical installation,

Table 1 Background and demographic characteristics of 446 participants

\begin{tabular}{|c|c|c|c|c|c|c|}
\hline Variables & Values & Institition1 & $\begin{array}{l}\text { Institution } \\
2\end{array}$ & $\begin{array}{l}\text { Institution } \\
3\end{array}$ & $\begin{array}{l}\text { Institution } \\
4\end{array}$ & Total \\
\hline \multirow[t]{5}{*}{ Age } & $18-25$ & $39.5 \%$ & $50.6 \%$ & $<1 \%$ & $2.1 \%$ & $92.6 \%$ \\
\hline & $26-35$ & $1.4 \%$ & $3 \%$ & $0 \%$ & $4 \%$ & $5.1 \%$ \\
\hline & $36-45$ & $0.5 \%$ & $0.7 \%$ & $0 \%$ & $0.9 \%$ & $2.1 \%$ \\
\hline & 46 and over & & $0.2 \%$ & & & $0 . \%$ \\
\hline & & & & & & $100 \%$ \\
\hline \multirow[t]{3}{*}{ Gender } & Male & $36.5 \%$ & $50.2 \%$ & $0.2 \%$ & $0 \%$ & $87 \%$ \\
\hline & Female & $4.9 \%$ & $4.2 \%$ & $0.2 \%$ & $3.7 \%$ & $13 \%$ \\
\hline & & & & & & $100 \%$ \\
\hline \multirow[t]{6}{*}{$\begin{array}{l}\text { Educational } \\
\text { level }\end{array}$} & $\begin{array}{l}\text { Bachelor's } \\
\text { degree }\end{array}$ & $0.2 \%$ & $1.2 \%$ & $0 \%$ & $0 \%$ & $1.4 \%$ \\
\hline & CSEC/A level & $28.4 \%$ & $32.6 \%$ & $0.2 \%$ & $1.9 \%$ & $63.1 \%$ \\
\hline & $\begin{array}{l}\text { Associate } \\
\text { degree }\end{array}$ & $0.2 \%$ & $0.2 \%$ & $0 \%$ & $0.5 \%$ & $0.9 \%$ \\
\hline & $\begin{array}{l}\text { Local } \\
\text { qualification }\end{array}$ & $5 \%$ & $4 \%$ & $0 \%$ & $0.2 \%$ & $9.5 \%$ \\
\hline & $\begin{array}{l}\text { Certificate/ } \\
\text { diploma }\end{array}$ & $7.3 \%$ & $15.6 \%$ & $0 \%$ & $0.5 \%$ & $23.4 \%$ \\
\hline & & & & & & $\begin{array}{l}98.3 \% \text { (missing } 1.7 \% \text { which } \\
\text { resulted from persons not } \\
\text { filling out section) }\end{array}$ \\
\hline \multirow{4}{*}{$\begin{array}{l}\text { Residential } \\
\text { location of } \\
\text { students }\end{array}$} & Chaguanas & $N=12$ & $N=41$ & $N=0$ & $N=7$ & $N=60 / 14 \%$ \\
\hline & $\begin{array}{l}\text { Couva/ } \\
\text { Tabaquite/ } \\
\text { Talparo }\end{array}$ & $N=18$ & $N=70$ & $N=1$ & $N=4$ & $N=93 / 21.4 \%$ \\
\hline & Penal/Debe & $N=13$ & $N=26$ & $N=0$ & $N=0$ & $N=39 / 9 \%$ \\
\hline & Tobago & $N=41$ & $N=20$ & $N=0$ & $N=0$ & $N=61 / 16 \%$ \\
\hline \multirow{5}{*}{$\begin{array}{l}\text { Course } \\
\text { pursuing }\end{array}$} & Auto mechanics & $N=19$ & $N=84$ & $N=0$ & $N=0$ & $N=103$ \\
\hline & $\begin{array}{l}\text { Electrical } \\
\text { installation }\end{array}$ & $N=42$ & $N=43$ & $N=0$ & $N=0$ & $N=85$ \\
\hline & $\begin{array}{l}\text { Industrial } \\
\text { instrumentation } \\
\text { maintenance }\end{array}$ & $N=57$ & $N=13$ & $N=0$ & $N=0$ & $N=70$ \\
\hline & $\begin{array}{l}\text { Information } \\
\text { technology }\end{array}$ & $N=1$ & $N=43$ & $N=0$ & $N=0$ & $N=44$ \\
\hline & $\begin{array}{l}\text { Tourism and } \\
\text { hospitality }\end{array}$ & $N=14$ & $N=5$ & $N=0$ & $N=16^{\prime}$ & $N=35$ \\
\hline
\end{tabular}


$n=70$ studied industrial instrumentation maintenance, $n=44$ pursued information technology, $n=16$ pursued cosmetology, and $n=19$ pursued tourism and hospitality which showed 76\% $(n=337)$ pursued the programmes mentioned above (Table 2). The remaining $24 \%$ would be from the other TVET programmes at the institutions.

\section{Summary of survey questions on student attitude and student's exposure to entrepreneurship education}

The survey questions are as follows (Table 3):

1. Are you thinking about going into your own business when you leave school?

2. Are you acquainted with the steps in setting up a business?

3. On a scale of $1-5$, please rate your response regarding the level of exposure you gained about running a business at your present school?

4. Do you think there are sufficient incentives for young people to become business owners?

5. Are you aware of government support for young persons to own their own business?

6. Do you think your present school is equipping students to become business owners?

7. How often does your school have classes on managing your own business?

8. How is managing your business taught at your school?

9. Do you think the knowledge and skills gained about running a business at your school would equip you to own your business?

\section{Research hypotheses}

The research hypotheses are as follows:

1. There is a relationship between student interest in pursuing entrepreneurship and exposure to entrepreneurship education.

Table 2 Showing courses students enrolled in

\begin{tabular}{ll}
\hline Courses & Number of students \\
\hline Air-conditioning & 22 \\
Auto mechanics & 103 \\
Carpentry & 1 \\
Cosmetology & 16 \\
Electrical installation & 85 \\
General draughtsman & 13 \\
Information technology & 44 \\
Industrial instrumentation maintenance & 70 \\
Jewelry craft & 1 \\
Machine shop & 10 \\
Welding & 42 \\
Plumbing & 5 \\
Tourism and hospitality & 19 \\
Total & 431 \\
Missing & 15 \\
\hline
\end{tabular}


Table 3 Survey items and participants' responses

\begin{tabular}{|c|c|c|c|c|c|c|}
\hline Survey item 2 & \multicolumn{3}{|l|}{ Yes } & \multicolumn{2}{|l|}{ No } & Uncertain \\
\hline $\begin{array}{l}\text { Acquainted with the steps in } \\
\text { setting up a business }\end{array}$ & \multicolumn{3}{|l|}{$\begin{array}{l}47.2 \% \\
(n=205)\end{array}$} & \multicolumn{2}{|l|}{$\begin{array}{l}15.4 \% \\
(n=67)\end{array}$} & $\begin{array}{l}36.9 \% \\
(n=160)\end{array}$ \\
\hline Survey item 3A & Never & \multicolumn{2}{|l|}{ Rarely } & Sometimes & Often & Always \\
\hline $\begin{array}{l}\text { When asked about skills in starting } \\
\text { your business }\end{array}$ & $\begin{array}{l}26.7 \% \\
(n=116)\end{array}$ & \multicolumn{2}{|l|}{$\begin{array}{l}19.8 \% \\
(n=86)\end{array}$} & $\begin{array}{l}22.8 \% \\
(n=99)\end{array}$ & $\begin{array}{l}13.6 \% \\
(n=59)\end{array}$ & $\begin{array}{l}11.3 \% \\
(n=49)\end{array}$ \\
\hline Survey item 3B & Never & \multicolumn{2}{|l|}{ Rarely } & Sometimes & Often & Always \\
\hline $\begin{array}{l}\text { Students were asked about } \\
\text { business management skills }\end{array}$ & $\begin{array}{l}30 \% \\
(n=130)\end{array}$ & \multicolumn{2}{|l|}{$\begin{array}{l}21.2 \% \\
(n=92)\end{array}$} & $\begin{array}{l}24.7 \% \\
(n=107)\end{array}$ & $\begin{array}{l}12.4 \% \\
(n=54)\end{array}$ & $\begin{array}{l}6.9 \% \\
(n=30)\end{array}$ \\
\hline Survey item 4 & $\begin{array}{l}\text { Strongly } \\
\text { agree }\end{array}$ & \multicolumn{2}{|l|}{ Agree } & Neutral & $\begin{array}{l}\text { Strongly } \\
\text { disagree }\end{array}$ & Disagree \\
\hline $\begin{array}{l}\text { Sufficient incentives for young } \\
\text { people to become business owners }\end{array}$ & $\begin{array}{l}7.4 \% \\
(n=32)\end{array}$ & \multicolumn{2}{|l|}{$\begin{array}{l}30 \% \\
(n=130)\end{array}$} & $\begin{array}{l}41 \% \\
(n=177)\end{array}$ & $\begin{array}{l}8.5 \%(n=37) \\
\text { strongly } \\
\text { disagree }\end{array}$ & $\begin{array}{l}13.1 \% \\
(n=70)\end{array}$ \\
\hline Survey item 5 & \multicolumn{3}{|l|}{ Yes } & \multicolumn{3}{|l|}{ No } \\
\hline $\begin{array}{l}\text { Awareness about government } \\
\text { support }\end{array}$ & \multicolumn{3}{|l|}{$\begin{array}{l}28.3 \% \\
(n=123)\end{array}$} & \multicolumn{3}{|l|}{$\begin{array}{l}70.3 \% \\
(n=305)\end{array}$} \\
\hline Survey item 6 & $\begin{array}{l}\text { Strongly } \\
\text { agree }\end{array}$ & \multicolumn{2}{|l|}{ Agree } & Neutral & $\begin{array}{l}\text { Strongly } \\
\text { disagree }\end{array}$ & Disagree \\
\hline $\begin{array}{l}\text { Equipping students to become } \\
\text { business owners }\end{array}$ & $\begin{array}{l}7.8 \% \\
(n=34)\end{array}$ & \multicolumn{2}{|l|}{$\begin{array}{l}22.4 \% \\
(n=97)\end{array}$} & $\begin{array}{l}40.8 \% \\
(n=177)\end{array}$ & $\begin{array}{l}10.1 \% \\
(n=44)\end{array}$ & $\begin{array}{l}13.1 \% \\
(n=70)\end{array}$ \\
\hline Survey item 7 & Never & $\begin{array}{l}\text { Once } \\
\text { per } \\
\text { week }\end{array}$ & $\begin{array}{l}\text { Twice } \\
\text { per } \\
\text { week }\end{array}$ & $\begin{array}{l}\text { Three times } \\
\text { per week }\end{array}$ & $\begin{array}{l}\text { Four times per } \\
\text { week }\end{array}$ & $\begin{array}{l}\text { Five times } \\
\text { per week }\end{array}$ \\
\hline $\begin{array}{l}\text { Frequency of business } \\
\text { management classes }\end{array}$ & $\begin{array}{l}78.6 \% \\
(n=341)\end{array}$ & $\begin{array}{l}14.5 \% \\
(n=63)\end{array}$ & $\begin{array}{l}2.5 \% \\
(n=11)\end{array}$ & $\begin{array}{l}0.7 \% \\
(n=3)\end{array}$ & $\begin{array}{l}0.5 \%(n=2) \text { of } \\
\text { students }\end{array}$ & $\begin{array}{l}2.1 \% \\
(n=9)\end{array}$ \\
\hline Survey item 8 & \multicolumn{3}{|c|}{ Core subject } & $\begin{array}{l}\text { Elective } \\
\text { subject }\end{array}$ & Not offered & \\
\hline $\begin{array}{l}\text { The method of teaching business/ } \\
\text { management }\end{array}$ & \multicolumn{2}{|c|}{$5.8 \%(n=25)$} & \multicolumn{2}{|c|}{$9.7 \%(n=42)$} & $79.7 \%(n=346)$ & \\
\hline
\end{tabular}

2. There is a relationship between student interest in pursuing entrepreneurship and student preparedness to set up a business.

3. There is a relationship between student interest in pursuing entrepreneurship and support and incentives.

4. There is a relationship between student interest in pursuing entrepreneurship and student attitude towards setting up a business.

Research questions are as follows:

1. Are there any linkages between students' interest in pursuing entrepreneurship and students being exposed to entrepreneurship education?

2. Are TVET students being furnished with adequate vocational skills training that would prepare them to become entrepreneurs?

3. Is there any connection between students' interest in entrepreneurship and state support and incentives?

4. Is there a relationship between interest and attitude involving TVET students towards entrepreneurship? 
Table 4 Spearman's correlation analysis

\begin{tabular}{|c|c|c|c|c|c|c|c|}
\hline & & & $\begin{array}{l}\text { Thinking } \\
\text { about going } \\
\text { into business } \\
\text { for yourself }\end{array}$ & $\begin{array}{l}\text { Level of } \\
\text { exposure } \\
\text { to business } \\
\text { training }\end{array}$ & $\begin{array}{l}\text { Knowing } \\
\text { the } \\
\text { importance } \\
\text { of business } \\
\text { skills }\end{array}$ & $\begin{array}{l}\text { Business } \\
\text { preparedness }\end{array}$ & $\begin{array}{l}\text { Support } \\
\text { and } \\
\text { incentives }\end{array}$ \\
\hline \multirow[t]{15}{*}{$\begin{array}{l}\text { Spearman's } \\
\text { rho }\end{array}$} & \multirow{3}{*}{$\begin{array}{l}\text { Thinking } \\
\text { about going } \\
\text { into business } \\
\text { for yourself }\end{array}$} & $\begin{array}{l}\text { Correlation } \\
\text { coefficient }\end{array}$ & 1.000 & $.132^{* *}$ & .050 & .060 & .040 \\
\hline & & $\begin{array}{l}\text { Sig. } \\
\text { (2-tailed) }\end{array}$ & . & .006 & .303 & .210 & .396 \\
\hline & & $N$ & 442 & 439 & 428 & 442 & 441 \\
\hline & \multirow{3}{*}{$\begin{array}{l}\text { Level of } \\
\text { exposure to } \\
\text { business } \\
\text { training }\end{array}$} & $\begin{array}{l}\text { Correlation } \\
\text { coefficient }\end{array}$ & $.132^{* *}$ & 1.000 & $.154^{* *}$ & .066 & .042 \\
\hline & & $\begin{array}{l}\text { Sig. } \\
\text { (2-tailed) }\end{array}$ & .006 & - & .001 & .169 & .384 \\
\hline & & $N$ & 439 & 442 & 430 & 442 & 442 \\
\hline & \multirow{3}{*}{$\begin{array}{l}\text { Knowing the } \\
\text { importance of } \\
\text { business skills }\end{array}$} & $\begin{array}{l}\text { Correlation } \\
\text { coefficient }\end{array}$ & .050 & $.154^{* *}$ & 1.000 & -.018 & $.192^{* *}$ \\
\hline & & $\begin{array}{l}\text { Sig. } \\
\text { (2-tailed) }\end{array}$ & .303 & .001 & - & .709 & .000 \\
\hline & & $N$ & 428 & 430 & 432 & 432 & 432 \\
\hline & \multirow[t]{3}{*}{$\begin{array}{l}\text { Business } \\
\text { preparedness }\end{array}$} & $\begin{array}{l}\text { Correlation } \\
\text { coefficient }\end{array}$ & .060 & .066 & -.018 & 1.000 & $.138^{* *}$ \\
\hline & & $\begin{array}{l}\text { Sig. } \\
\text { (2-tailed) }\end{array}$ & .210 & .169 & .709 & - & .004 \\
\hline & & $N$ & 442 & 442 & 432 & 446 & 445 \\
\hline & \multirow[t]{3}{*}{$\begin{array}{l}\text { Support and } \\
\text { incentives }\end{array}$} & $\begin{array}{l}\text { Correlation } \\
\text { coefficient }\end{array}$ & .040 & .042 & $.192^{* *}$ & $.138^{* *}$ & 1.000 \\
\hline & & $\begin{array}{l}\text { Sig. } \\
\text { (2-tailed) }\end{array}$ & .396 & .384 & .000 & .004 & - \\
\hline & & $N$ & 441 & 442 & 432 & 445 & 445 \\
\hline
\end{tabular}

**Correlation is significant at the 0.01 level (2-tailed)

These hypotheses were tested using Spearman's correlation analysis with data from survey items 1-9. Table 4 illustrates the findings for these hypotheses.

For this study, each hypothesis was tested using Spearman's correlation coefficient (rho). This allowed the researchers to ascertain the existence of any correlations, the direction of correlations, and at what level of significance the null hypotheses are rejected in favour of the alternative hypotheses or accepted in the absence of significance. A Spearman correlation for the collective sample was performed, where all the variables were tested with the dependent variable, interest in pursuing entrepreneurship, and their correlation coefficients generated. Level of exposure was the only variable which exhibited a correlation (rho $=.132, N=439, P=.006$, two-tailed).

Another important finding in conducting the correlation analysis for the pooled sample was that some of the independent variables showed a correlation with one another. The results showed the strongest relationship was found to exist between knowing the importance of entrepreneurship and the availability of support and incentives (rho $=.192, N=432, P=.000$, two-tailed), knowing the importance of entrepreneurship and the level of exposure to entrepreneurship (rho $=.154, N=430, P=.001$, two-tailed), and then preparedness to own a business and the availability of support and incentives (rho $=.138, N=445, P=.004$, two-tailed). 
Table 5 Relationship between student interest in pursuing entrepreneurship and exposure to business training

\begin{tabular}{lllll}
\hline & & $\begin{array}{l}\text { Thinking about going into } \\
\text { business for yourself }\end{array}$ & $\begin{array}{l}\text { Level of exposure to } \\
\text { business training }\end{array}$ \\
\hline $\begin{array}{l}\text { Spearman's } \\
\text { rho }\end{array}$ & $\begin{array}{l}\text { Thinking about going into } \\
\text { business for yourself }\end{array}$ & $\begin{array}{l}\text { Correlation } \\
\text { coefficient }\end{array}$ & 1.000 & $.132^{* *}$ \\
& Sig. (2-tailed) & - & .006 \\
& $N$ & 442 & 439 \\
& Level of exposure to & Correlation & $.132^{* *}$ & 1.000 \\
business training & coefficient & & - \\
& Sig. (2-tailed) & .006 & 442 \\
\hline
\end{tabular}

${ }^{* *}$ Correlation is significant at the 0.01 level (2-tailed)

H1. There is a relationship between student interest in pursuing entrepreneurship and exposure to business training (Table 5).

The results of Spearman's correlation for the sample indicated that the level of exposure to entrepreneurship training was significantly associated with interest in entrepreneurship (rho $=.132, N=439, P=.006$, two-tailed). Therefore, the results show that the null hypothesis is rejected in favour of the alternative. Therefore, there is a positive relationship between TVET students' level of exposure to entrepreneurship training and interest in owning their own business. Therefore, the greater the level of exposure to entrepreneurship, the more TVET students reporting interest in pursuing entrepreneurship/owning their own business.

\section{Logistic regression}

A logistic regression analysis was conducted to predict causes of TVET students' interest in pursuing entrepreneurship (dependent variable), for 446 TVET students, using level of exposure to entrepreneurship training, the importance of entrepreneurship skills, level of preparedness to set up a business, and support and incentives as the four predictors/independent variables (Table 6). A test of the full model against a constant only model was statistically significant, indicating that the predictor variables as a set reliably distinguished between those who indicated interest in pursuing entrepreneurship and those who indicated no interest in pursuing entrepreneurship (chi-square $=9.887, P=.042$ with $\mathrm{df}=4$ ).

Table 6 Variables in the equation

\begin{tabular}{|c|c|c|c|c|c|c|c|c|c|}
\hline \multicolumn{10}{|c|}{ Variables in the equation } \\
\hline & & \multirow[t]{2}{*}{ B } & \multirow[t]{2}{*}{ SE } & \multirow[t]{2}{*}{ Wald } & \multirow[t]{2}{*}{$\mathrm{df}$} & \multirow[t]{2}{*}{ Sig. } & \multirow[t]{2}{*}{$\operatorname{Exp}(B)$} & \multicolumn{2}{|c|}{ 95\% Cl for $\operatorname{Exp}(B)$} \\
\hline & & & & & & & & Lower & Upper \\
\hline \multirow[t]{5}{*}{ Step $1^{a}$} & Exposure & .024 & .009 & 7.907 & 1 & .005 & 1.025 & 1.007 & 1.042 \\
\hline & Skills importance & -.007 & .010 & .519 & 1 & .471 & .993 & .975 & 1.012 \\
\hline & Preparedness & .048 & .055 & .758 & 1 & .384 & 1.049 & .942 & 1.168 \\
\hline & Support and incentives & .047 & .065 & .535 & 1 & .465 & 1.049 & .923 & 1.191 \\
\hline & Constant & .154 & .700 & .049 & 1 & .825 & 1.167 & - & - \\
\hline
\end{tabular}

${ }^{a}$ Variable(s) entered on step 1: exposure, skills importance, preparedness, and support and incentives 
That is, the model successfully predicted $81.2 \%$ of the cases. Although only a moderately strong classification percent, the figures are within the generally accepted classification range. The Nagelkerke $R$ square of .037 indicated a very weak relationship between the dependent and independent variables. That is, $3.7 \%$ of the variability (or change) in the dependent variable is accounted for by the inclusion of the independent variables in the regression model.

Also, the Hosmer and Lemeshow statistic is greater than .05 which means that the null hypothesis of no difference between the observed and predicted models is rejected. Therefore, the alternative hypothesis is accepted which states that there is a difference between the observed and predicted models. That is, the H-L has a statistic of .362 that is not statistically significant which means that the model's estimates fit the data at an acceptable level.

The Wald statistic indicates the significance of each predictor. In this regression analysis, the Wald criterion demonstrated that one factor, level of exposure to entrepreneurship training $(P=.005)$, made a significant contribution to the prediction where $P<.05$.

Therefore, the level of exposure TVET students have to entrepreneurship training at their schools influences their desire or interest in pursuing the development of their own business, as these two variables showed statistical significance in the analysis. The other three independent variables did not show any statistical significance with the dependent variable.

\section{Discussion}

The research sought to provide insights on entrepreneurship education within TVET institutions in T\&T. The research provided revelations involving the level of exposure to entrepreneurship education. The study pinpointed that there is a lack of entrepreneurship education at TVET institutions. The study highlighted the level of exposure towards entrepreneurship education students received that would enable them to pursue entrepreneurship. The research provided three (3) findings that emanated from the results which will be further articulated to allow the reader to gain a deeper understanding of the issues involved in the study. They included exposure, preparedness, and support and incentives.

\section{Exposure}

The findings revealed that there was a significant relationship between exposing students to entrepreneurship education and students interest in entrepreneurship (rho $=.132, N=439, P=.006$, two-tailed). An interesting study that was done found that students that experienced entrepreneurship education are more inclined to have better entrepreneurial aspirations as compared to students who were not exposed to entrepreneurship courses (Gerba 2012). More knowledge about entrepreneurship education can result in students having more convincing views on entrepreneurship interest (Ibrahim, Bakar, Asimiran, Mohamed, \& Zakaria, 2015). More emphasis should be placed on students, to pursue entrepreneurship education. Providing students with the right environment and the tools can go a long way in them becoming entrepreneurs. According to Cho, Robalino, and Watson (2016), training is a strategic scheme 
for constructing entrepreneurial capability. These revelations are insightful and provide a very good rationale for exposing students in $T \& T$ along entrepreneurial paths. Cho et al. (2016) in a study entitled 'Supporting self-employment and small-scale entrepreneurship: potential programmes to improve livelihoods for vulnerable workers' provided deep insights on the value of training along entrepreneurship lines. The study revealed the importance of training persons along entrepreneurial paths. The study highlighted that the training was geared to improve the earnings of small-scale entrepreneurs. The training participants received involved courses exposing them to education relating to becoming better business owners.

Another point was endorsed by Ibrahim et al. (2015) which stated that greater knowledge about entrepreneurship education can result in students having more convincing views on entrepreneurship interest. The points articulated by the authors justified the researchers' position and the findings from the research, which states that exposing the TVET students to entrepreneurship can propel students to become entrepreneurs. It endorses the correlation between students' interest to pursue entrepreneurship education and exposing students to entrepreneurship education. This occurrence is an astonishing finding, and it should be welcomed by TVET institutions and administrators. Exposing students to entrepreneurship should be carried out constantly, and going forward, TVET institutions within T\&T should consider these findings and put them into effect.

\section{Preparedness}

Providing students with adequate vocational training is just as important as giving them entrepreneurial training. The rationale is that once TVET students are provided with the correct vocational training, they can have the adequate tools to pursue a business, then having been exposed to entrepreneurial education will provide students with an arsenal of skills that can go a long way. The study did not provide any correlation with student interest in pursuing entrepreneurship and business preparedness. Nevertheless, it is important for students to have ample vocational skills and training that they can be an asset to the country and society.

More can be done to provide students with adequate vocational training. Students require training that will contribute towards economic development, social advancement, and national progress, and TVET training with entrepreneurship provides this reality. Wolf and Erdle (2009) shared a few deep and thoughtful opinion which states that TVET and sustainable economic growth are connected. According to the Ministry of Sport and Youth Affairs (2000) of T\&T, the unemployment levels for the young population account for $36-40 \%$ in T\&T. Additionally, NYP (n.d) states that many of the T\&T youth are excluded from social and economic development and abide in poverty-stricken neighbourhoods with limited resources. Based on these discussions and revelations, TVET can be an instrumental tool in assisting T\&T's development.

Another insightful revelation was provided by a committee in T\&T; the committee conducted research that focused on the at-risk young male, entitled 'No time to quit: Engaging Youth at Risk'. The study shared informative ideas endorsing TVET. According to Ryan, Rampersad, Bernard, Mohammed, and Thorpe (2013), TVET institutions have systems that can be used as a practical and strategic instrument for tackling the various challenges of the disadvantaged youth that joined their programmes. However, Ryan et al. 
(2013) expressed the view that the TVET system needed reform that would play a vital role in advancing the vision for sustainable development within T\&T. These utterances reveal a very good narrative and show the need for TVET institutions to deliver training that creates the right environment for their students to be equipped and prepared to face the world of work. TVET students once provided with adequate skills training not to mention, entrepreneurial training can give students a collection of resources to their benefit.

\section{Support and incentives}

Also, another finding was knowing the importance of entrepreneurship and the availability of support and incentives, which had less significant correlation to the first finding; nevertheless, it provided insight into the importance of support and incentives towards entrepreneurship.

Although there was little correlation involving support and incentives, there is an important role the government can play in promoting entrepreneurship. Encouraging entrepreneurship is a vital instrument for a country's development. Fuerlinger, Fandl, and Funke (2015) stated that numerous scholars have put forward the view that providing entrepreneurship policy that focuses on developing entrepreneurship creates a positive effect on the country's economy. Therefore, the role of the government is critical in promoting entrepreneurship within the country (Fuerlinger et al., 2015). Incentives are an extremely important tool in strengthening entrepreneurship. Incentives that encourage productive entrepreneurship results impact positively on economic development (Aidis \& Estrin, 2013). This shows the value and importance incentives bring to TVET within Trinidad and Tobago. Students should be made aware of the various support programmes available and be provided with various incentives that can facilitate individuals having greater encouragement and opportunities to pursue entrepreneurship as a career path.

\section{Research gaps}

T\&T skills policy is not extensive and does not provide a clear direction on the way forward for TVET. Additionally, the National Youth Policy of T\&T as cited by the Ministry of Sport and Youth Affairs (2000) does not provide linkages with TVET or articulate a position on TVET or entrepreneurship. Not to mention, the data given by the NYP is from 1998 and no modern statistics are given that will inform what is happening at current. T\&T has a policy document for entrepreneurship which is not detailed and extensive which may not provide the required framework that will facilitate a robust entrepreneurial culture and environment that can generate the required results for positive entrepreneurial growth. Lastly, the study only focused on four TVET institutions and did not take into account other institutions within the Republic of T\&T. Thus, the information and data gathered will be limited to the institutions that are part of the study. All of these issues contributed to limitations within the research. According to Ramkissoon-Babwah (2012) commenting on a study done on the entrepreneurial education model for T\&T stated that there is a dearth of research material that would not inform or contribute to ideas concerning entrepreneurial education within the wider Caribbean context. 


\section{Conclusions and recommendations}

The study focused on four TVET institutions; the intention was to examine the entrepreneurship education content within these TVET institutions. The institutions in question provided a wide array of courses in many vocational lines. The TVET institutions were tertiary level institutions of learning, which demonstrates their significance and role in the development of the nation of T\&T human resources. The study also unearthed the value and importance of TVET towards a country's development. TVET was seen as a catalyst for economic prosperity and social benefit to the society and the country. Additionally, TVET was viewed as an important facet to assist in the eradication of unemployment, especially within the young population.

The literature articulated the role entrepreneurship can play in bringing about social and economic transformation. Entrepreneurship education was put forward as a vital arsenal in the armoury of TVET institutions. Entrepreneurship education was seen as an important role in developing people that can produce positive results. The study is very important as it provides insight into some of the entrepreneurship education practices of four TVET institutions. Information shared revealed a lack of entrepreneurship education at the institutions. The study revealed many areas that are lacking regarding entrepreneurship education. Another important development was students' interest to pursue entrepreneurship education which was significantly high, and most students surveyed had an interest in pursuing entrepreneurship education. The frequency and availability of entrepreneurship education classes are non-existent in most cases. The interest from students indicates that placing entrepreneurship education with the TVET curricula can be of significant value to them. This is an initiative which will be welcomed by the students. The idea of support and incentives shared insightful ideas about their importance in offering entrepreneurship education. Valuing the role of support and incentives has to be considered in light of offering entrepreneurship education. It has importance, so it should be considered.

The findings from the study provide a very good opportunity for TVET institutions to embrace and utilise the data to inform their practices. Exposing students to entrepreneurship education within TVET institutions revealed a significant correlation that provides their organisation with an imperative tool to advance an agenda that will promote TVET and contribute to the human resource capital of T\&T.

Abbreviations

SPSS: Statistical Package for the Social Sciences; T\&T: Trinidad and Tobago; TTYP: Trinidad and Tobago Youth Policy; TVET: Technical and Vocational Education and Training; UWI: University of the West Indies

Acknowledgements

Not applicable.

Authors' contributions

AM conceived and designed the study and also the research instruments, participated in the sequence alignment, and drafted the manuscript. DW participated in the design of the study and in the sequence alignment and assisted with designing the research instruments. OS participated in the designing of the research instruments and did the statistical analysis. All authors read and approved the final manuscript.

Funding

Funding was not provided for the article from any funding body or organisation. 


\section{Competing interests}

The authors declare that they have no competing interests.

\section{Author details}

${ }^{1}$ University of Trinidad and Tobago, Lot 74-98 O'Meara Industrial Estate, Arima, Trinidad and Tobago. ${ }^{2}$ Talparo, Trinidad and Tobago. ${ }^{3}$ Chaguanas, Trinidad and Tobago.

Received: 20 February 2019 Accepted: 4 July 2019

Published online: 23 July 2019

\section{References}

Aidis, R., \& Estrin, S. (2013). 'Institutions, incentives and entrepreneurship' chapter 3. In Z. Acs, L. Szerb, \& E. Autio (Eds.), The Global Entrepreneurship and Development Index 2013 (pp. 18-26). Edward Elgar.

Anderson, D. (2009). Productivism and ecologism: changing dis/courses in TVET. In J. Fien, R. Maclean, \& M.-G. Park (Eds.), Work, Learning and Sustainable Development (Vol. 8, pp. 35-37).

Aring, Monika. Promising Youth Development Strategies. Education. Education Development Center, Inc, 2011. Online. Beardwell, I., Holden, L., \& Claydon, T. (2004). Human resource management a contemporary approach. England: Pearson Education Limited.

Boxill, I., Chambers, C., \& Wint, E. (1997). Introduction to social research. Kingston: Canoe Press University of the West Indies.

Cho, Y., Robalino, D., \& Watson, S. (2016). Supporting self-employment and small-scale entrepreneurship: potential programs to improve livelihoods for vulnerable workers. IZA Journal of Labor Policy.

Edmond, A., Oluniyi, A., Isaiah, D., \& Garba, B. (2014). Strategies for revitalizing the implementation of entrepreneurship education in Technical, Vocational Education and Training (TVET) to enhance self-employment in Nigeria. British Journal of Education, 2(4), 50-62.

Fuerlinger, G., Fandl, G., \& Funke, T. (2015). The role of the state in the entrepreneurship ecosystem: insights from Germany. Triple Helix.

Gallo, A. (2015). A Refresher on Regression Analysis. Harvard Business Publishing. Retrived from: https://hbr.org/2015/11/arefresher-on-regressionanalysis.

Gerba, D. T. (2012). Impact of entrepreneurship education on entrepreneurial intentions of business and engineering students in Ethiopia. African Journal of Economic and Management Studies, 3.2(2012), 258-277. https://doi.org/10.1108/204 00701211265036

Glenn, I. D. (1992): Sampling the Evidence of Extension Program Impact. Program Evaluation and Organizational Development, IFAS, University of Florida.

Ibrahim, W. N., Bakar, A. R., Asimiran, S., Mohamed, S., \& Zakaria, N. S. (2015). Impact of entrepreneurship education on the entrepreneurial. 8. Malaysia: Canadian Center of Science and Education. https://doi.org/10.5539/ies.v8n12p141.

Kelley, D. J., Bosma, N., \& Amorós, O. J. E. (2011). Global Entrepreneurship Monitor 2010. Global Report.

Maigida, J. F., Saba, T. M., \& Namkere, J. U. (2013). Entrepreneurial skills in technical vocational education and training as a strategic approach for achieving youth empowerment in Nigeria. International Journal of Humanities and Social Science.

Ministry of Tertiary Education and Skills Training. (2015). The future of tertiary education and skills training 2015-2025. Retrieved from http://moe.gov.tt/portals/0/Documents/Publications/TESTNationalPolicyFramework2015-2025.pdf

Myamba, B. M. (2013). Streamlining TVET system for entrepreneurship development. CAPA Scientific Journal.

Phillip O. Nwachukwu. (2014). Poverty Reduction through Technical and Vocational Education and Training (TVET) in Nigeria. Developing Country Studies. (Paper) ISSN 2225-0565 (Online) Vol. 4, No. 14, 2014. Retrived from: https://pdfs. semanticscholar.org/cfc4/ea96fa95a64f6a8f1d404edb187f56c47ab9.pdf.

Ramkissoon-Babwah, Natasha. "An entrepreneurship education model for Trinidad and Tobago." Journal of Emerging Trends in Educational Research and Policy Studies (2012): 307-311. ISSN: 2141-6990. Online. December 2017. jeteraps. scholarlinkresearch.org

Ryan, S., Rampersad, I., Bernard, L., Mohammed, P., \& Thorpe, M. (2013). No time to quit: engaging youth at risk. St. Augustine: Multimedia Production Centre Retrieved from https://www.undp.org/content/dam/trinidad_tobago/docs/ DemocraticGovernance/Publications/RyanReport.pdf.

Singh, Ajay and Micah Masuku. "Sampling techniques \& determination of sample." International Journal of Economics, Commerce and Management II. 11 (2014). 2018. http://ijecm.co.uk/wp-content/uploads/2014/11/21131.pdf.

Tambunan, T. (2019). Recent evidence of the development of micro, small and medium enterprises in Indonesia. Journal of Global Entrepreneurship Research.

Ministry of Sport and Youth Affairs (2000). The National Youth Policy . Port-of-Spain: Ministry of Sport and Youth Affairs. Retrieved from http://www.youthpolicy.org/national/Trinidad_Tobago_2004_National_Youth_Policy.pdf

Wolf, A., \& Erdle, A. (2009). Key aspects of the economics of Technical and Vocational Education and Training (TVET) lessons learned and gaps to be filled. Eschborn: Deutsche Gesellschaft für Technische Zusammenarbeit (GTZ) GmbH.

\section{Publisher's Note}

Springer Nature remains neutral with regard to jurisdictional claims in published maps and institutional affiliations. 